\title{
The Analysis of Code Switching in the Novel "Critical Eleven" by Ika Natasha
}

\author{
Gusti Putu Larasani*, I Gede Sadia \\ English Department, Faculty of Arts, Udayana University \\ [larasayugp@gmail.com] \\ *Corresponding Author
}

\begin{abstract}
The undergraduate thesis is entitled "The Analysis of Code Switching in the Novel "Critical Eleven" By Ika Natasha". The aim of this study is to analyze type and function of code switching in the novel. The novel entitled "Critical Eleven" was chosen because this novel is a great novel and the dialogues use many code switchings. There are two problems to be investigated: First, What types of code switching were found in this novel? And the second one What kinds of function of code switching were applied in this novel? The method used in collecting data was the documentation method and the data were analyzed using the theory proposed by Muysken in "The Cambridge Handbook of Sociolinguistics". The result of this study shows that there were seventeen examples of tag switching, twenty four examples of inter sentential switching and fifty six examples of intra sentential switching. There were six examples of emotive function, two examples referential function, four examples of phatic function, five examples of metalinguistic function and only one example of poetic function but the conative function was not found.
\end{abstract}

\section{Keywords: Language, Code Switching, Novel}

\begin{abstract}
Abstrak
Penelitian ini berjudul "Analisis Alih Basah adalam novel "Critical Eleven"oleh Ika Natasha. Tujuan dari penelitian ini adalah untuk membahas tipe dan fungsi alih bahasa yang di temukan pada novel tersebut. Novel berjudul "Critical Eleven" ini dipilih dikarenakan novel ini sangat menarik dan banyak mengandung alih bahasa di percakapannya. Pada penelitian ini terdapat dua masalah yang di bahas, yang pertama adalah tipe code switching apa yang dapat di temukan di novel ini dan yang kedua adalah fungsi code switching apa saja yang dapat di temukan di novel ini.Metode yang digunakan dalam mengumpulkan data adalah metode dokumentasi dan data yang telah di kumpulkan di análisis dengan teori yang ditulis oleh Muysken yang dalam bukunya berjudul "The Cambridge Handbook of Sociolingistics". Hasil dari penelitian ini menunjukan bahwa ada tujuhbelas contohdari Tagswitching, duapuluh empat cuntoh dari inter sentential switching dan lima puluh enam contoh dari intrasentential switching. Selain ditemukan enam contoh dari emotive function, dua contoh dari referential function, empat contoh dari phatic function, lima contoh dari metalinguistic function dan satu contoh dari poetic function.
\end{abstract}

\section{Kata Kunci : Bahasa, Alih Bahasa, Novel}




\section{Background of the Study}

Language is the way a person could interactand communicate with others; besides, language is also the way to express one's felling and thought, to deliver information and many more. Language is very important for human life.Since someone was born she or he haslearnt his or her mother tongue and whenshe or heis grown up,she or he are also learns the second language directly. According to Hudson, language is basically a set of items called "Linguistic Items" such as the unit of sound, word, grammatical structure and so on. Those linguistic items have functions and aims. According to Peter Robinson and Abigail Locke, the social physiological of language is to give the representation of singing, speaking, reading and writing. Language can be in the form of writing, sign, sound which has structure, grammar, and meaning. Language and society can't be separated and that is called Sociolinguistics. According to Gumperz, Sociolinguistics is an effort to find the relation between social structure and linguistic structure and also to observe the change that can occur. According to Cambers, Sociolinguistics is the study of social use of language, and according to Wardhaugh, sociolinguistics is the relationship between language and society. The relation of both has the aim to find the better understanding of the structure of language and language function in communication relation. Sociolinguistics can also mean the study of both relation between language and 'society and has the aim to observe the understanding of language structure, and function that can be changed. Sociolinguistics is a wide science and has a large scope that can be learned but only Code Switching is discussed in this study; in general, code switching is the phenomenon of the action of switching from one language to another language in the same utterance and has function and meaning. According to Muysken, Code
Switching is the use of more than one language during a communicative event. "Further Comments" on what code switching means is explained byMuysken. First "The use" most of the code switching study is focused on production and not perception. "Of more than one" means that there is no limitation of two languages in code switching and then "Language" code switching is needed to be present from more than one language and the last "During a single communicative event" code switching can happen in the conversation or when passing and reading a bilingual road sign. According to Romaine code switching is the utterance in which more than one language is used and combined in different ways and also happen in some degree. And according to Wardhaugh, Code switching occurs in a multilingual situation when language can change according to situation, and the language fits the message. Therefore, code switching is the change or switch from one language to another language during the conversation and often develops in bilingual or multilingual communities.

Indonesia has thirty four provinces and actually every region has their own language. Indonesia has around 742 languages and Bahasa is an official and national language. Indonesia is a multilingual country; therefore, Indonesians can use code-switching in their daily conversation. The use of code switching is a usual phenomenon in the daily conversation. Code switching can represent a good English knowledge of a person. Because most magazines, newspapers, novels and TV programs apply code switching to convey an information.

Critical Eleven is one ofthe great novels written by Ika Natassa; this novel tells about eleven minutes of critical circumstances in the plane.There are two characters in this novel; they are Ale and Anya. They met during flight Jakarta to 
Sydney. On the first three minutes, they both were mesmerized, seven hours during the flight to Sydney they were sitting next to each other and getting acquainted while chatting and laughing and on the last eight minutes before saying good bye Ale was falling in love with Anya. But after five years they met, Ale and Anya had a great tragedy and put them on the hard choice. Code-switching is very interesting phenomenon to talk about. Code-switching is necessary for human life when people are able to speak more than one language it will be a strength to have a wide relation with many people making their life easier. They can have interaction with people coming from abroad and, actually, add their insight and show the social class.

\section{Problems of the Study}

Based on the background explained above, there are three problems to be investigated; they are:

a. What types of code switching were found in this novel?

b. What kinds of function of code switching were applied in this novel?

\section{Aims of the Study}

There are three aims to be achieved in this study; and they are:

a. To find out the type of code switching used by the characters in this novel.

b. To find out the function of code switching used by the characters in this novel.

\section{Research Method}

The research method in this study consists of data source, method and technique of collecting data, method and technique of analyzing data.

\subsection{Data Source}

This study used written data, which is the novel entitled "Critical Eleven" by IkaNatassa. This novel was published by
Gramedia in 2015 and consists of 334 pages. This novel was chosen because Critical Eleven is a novel which uses a lot of code switching from Indonesianinto English in the dialogues.

\subsection{Method and Technique of Collecting Data \\ There were two methods of} collecting data in this study and those are documentation and library research and there were four techniques of collecting data, those are:

a. The first technique was reading the novel several times.

b. Second underlining the sentences which contain code switching

c. Third note taking the code switching.

d. Fourth grouping the sentences into three types of code switching.

\subsection{Method and Technique of Analyzing Data}

This study used qualitative method because the data were a written text. There were some steps of analyzing data, they are:

a. First understanding the concept of the type of code switching and also the function of code switching proposed by Muysken (2011)

b. Second, classifying the data into the types and functions of code switching.

c. And the last stepswas analyzing and describingthe data based on the theory used.

\section{Analysis}

5.1 The Analysis of Types of

\section{A. Tag Switching}

Tiga menit pertama saat bertemu seseorang itu kritis sifatnya dari segi kesan pertama, right?

The remark above is tag switching because in the last utterance the speaker inserts English language "right?" and 
begins with Indonesian language "Tiga menit pertama saat bertemu seseorang itu kritis sifatnya dari segi kesanpertama"; the use of the word "right" in Indonesian language is so familiar; the speaker used this word to make sure that the listener agreed with what she was talking about.

\section{B. Inter-Sentential Switching}

In the hours that we're still on the plane, sama dengan satu jam sikucing terkurung dalam kotak, people are left with a paradox 50-50 chance that we still live on board.

The remark above is classified into inter sentential switching, there was Indonesian language between English language in one clause. Speakers uses Indonesian language "sama dengan satu jam sikucing terkurung dalam kotak" to tell listener that she was equalized theirself by a caged cat on the box when they was one the plane and she also stated that when we on the plane we don't know we will a live or not. Because when we in the plane our live is on pilot hands.

\section{Intra Sentential Switching}

Lah yang pertama ketemu malah Anya yang selfie kami berdua dengan satu tangannya menjewer kuping gue

The utterance above is found intra sentential switching because there was insertion of English language in the middle of this utterance "selfie" which is has means "swafoto" in Indonesian language. But most of Indonesian used selfie in their daily converstation and the intention of this expression was remain the memories of a selfie fhoto that he was found.

\subsection{The Analysis of Function of Code Switching}

A. Emotive Function

Come on! Gue manggil Ale 'bro', ya gue manggil lo 'sis' dong."
Regarding the function of code switching, the utterance above is classified as having the emotive function. The speaker began the expression using English language and then followed by Indonesian language. The speaker usedthe exclamation "Come on!" to make the listener agree with his argument.

\section{B. Referential Function}

Karena saat ini tukang $A C$ aja lebih pintar daripada lo, Tanya Baskoro. Hati itu bisa disetel kayak AC.

The examples above is classified to referential function, because in the middle of Indonesian language was found insertion of English "AC" AC is Air conditioner and in Indonesian language has mean "Pendingin Ruangan". Called $\mathrm{AC}$ is better then "pendingin ruangan" in Indonesian beside that was more simple when someone pronounce AC.

\section{Phatic Function}

"Not having the option to leave takes the joy out of everything, iya nggak?"

The example above is classified as having phatic function because there is a tag of English language in the end of this expression " iya nggak" when the speaker said "iyanggak", the tone changed. The speaker used this utterance to make sure that the listener agreed with what the speaker was talking about.

\section{Metalinguistic Function}

Ale dulu suka diam-diam iseng menyelipkan Post-it "catatan penting" versi dia di beberapa lembar majalah atau buku itu.

Same as the example number three, the utterance above belonging into metalinguistic switching. There was insertion of english language in this phrase "Post-it" and then speaker also utter the same meaning of post it which is "catatan kecil" in one utterance. The intention of this utterance was expressd 
that her husband used to slip a "post it" in her book.

\section{E. Poetic Function}

See, Nya, air dingin nggak bias membunuh kenangan.

The utterance above has poetic function,because this utterance is intended to convey message to the listener. The speaker told the listener that cold water cannot delete all memories.

\section{Conclusion}

There are three types of code switching in the novel entitled "Ctitical eleven bylka Natasha". First, we could findseventeen examples of tag switching, twenty four examples of inter sentential switching and fifty six examples of intra sentential switching. So, the most used type of switching was intra sentential switching. Besides, we could find five functions of switching in this novel from the six proposed by Jakobson. There were six examples of emotive function, two examples referential function, four examples of phatic function, five examples of metalinguistic function and only one example of poetic function but conative function was not found. So from the six functions only five functions of switching were found and the most frequently used is the phatic function.

\section{Bibliography}

Fatimah, S.T. (2016). Code Switching Made by Presenters of Music Program Breakoutnet(thesis). Udayana University, Denpasar.

Korban, D. (2013). Intra-sentential and Inter-sentetial Code Switching in Turkish-English Bilinguals in New York City, US .Hacettepe University, Turkey.

Nafiah, I. (2013). An Analysis of Code Switching in the novel Miss
PesimisBy Alia Zalea (thesis). State Islamic College, Tulungagung.

Natalia, E. V. (2009). The Analysis of Code Switching in Femina Magazines (thesis). UdayanaUniversity, Denpasar.

Natassa, I. (2015). Critical Eleven. PT GramediaPustakaUtama, Jakarta.

Nisa, C. (2014). An Analysis of Code Switching in Supernova: Ksatria,PutriddanBintangJatuh Novel By DewiLestari.Kajuruhan University, Malang.

Romaine, S. (2000). Language in Society. Oxford University Press, New York.

Wardhaugh, R. (2006). An Introduction to Sochiolinguistics. Blackwell, Australia.

Mesthrie, R. (2011). The Cambridge Handbook of Sociolingistics. Cambridge University Press, UK. 